\title{
Psychological Contract Breach and Organizational Outcomes: Moderating Effect of Tenure
}

\author{
Sabu Varghese ${ }^{1}$ and M.S. Raju ${ }^{2}$ \\ ${ }^{1}$ Research Scholar, \& ${ }^{2}$ Professor, School of Management and Entrepreneurship \\ Kerala University of Fisheries and Ocean Studies, Kerala, India \\ E-Mail: svargh@gmail.com
}

\begin{abstract}
Conventional wisdom tells us that only if the employees are paid enough, they can be made happy consequently productive. However, studies have suggested that the nature of the relations between employer and employee have a vital role to play in employee's job satisfaction, Likewise, employee's intention to leave the organization is influenced by both money related factors and relational elements. Studies suggest that the nature of the employer-employee relationship significantly affects the employee perceptions and reactions. Psychological Contract is a model which will help one to understand the employeremployee relationship. The mutual expectations and obligations proportionate to each one's contribution is a general way to define psychological contract. Research suggests that a breach of this contract can affect the organizational outcomes and employee reactions negatively. This study considers the psychological contract breach from the employees' perspective. Although studies have been made on the effect of psychological contract breach on several organizational outcomes, little effort has been noticed to be made to study the effect of the commonly identified dimensions - relational contract breach and transactional contract breachon the employee reactions. While social and emotional factors such as loyalty and support contribute to relational contract, compensation and personal benefits contribute to transactional contracts. This work is noteworthy as it assesses the effect of relational contract breach and transactional contract breach on job satisfaction and employee turnover intention. The study also examines the effect of individual level variable- tenure - on the relationship of $\mathrm{RCB}$ and TCB with job satisfaction and turnover intention. Respondents to this study were 228 teachers from the self-financing colleges in the district of Ernakulam, Kerala in India. The results suggest that relational and transactional contract breaches will lead to significant employee reactions- reduces job satisfaction and enhances turnover intention. Tenure moderates the relationship between relational contract breach and turnover intention but not between relational contract breach and job satisfaction. Conversely, tenure moderates the transactional contract breach- turnover intention relationship but not transactional contract breach- job satisfaction.
\end{abstract}

Keywords: Psychological Contract Breach (PCB), Relational Contract Breach (RCB), Transactional Contract Breach (TCB), Job Satisfaction (JS), Turnover Intention (TI), Tenure.

\section{INTRODUCTION}

The role of Psychological contract is gaining more importance in the changing organizational environment with the shifting tides of globalization, restructuring, organizational agility and collaborative leadership, as the breach or fulfillment of this contract leads to negative or positive organizational outcomes. The relationship between employer and employee is determined by the degree of fulfillment of psychological contract. Psychological contract refers to mutual expectations and obligations between an employer and employee. Unlike formal contract, psychological contract is unwritten set of expectations the employers and employee mutually have. As perceptions lead to behavior, it is of interest to the organizations to find out the perception of their employees about the fulfillment of this unwritten contract from the employers' side and how they behave based on this perception. The concept of psychological contract is equally or more relevant in educational institutions as compared to any other organization.

The teachers, at the time of joining or in the early stages of their career, enter into a psychological contract with the management by holding the beliefs that they are entitled to receive a regular salary hike, appreciation from the management, benefits for staying late or compensating for their overtime work. During the course of their job, if the teachers perceive that the management has not been fulfilling their expectations or not meeting their perceived obligations, it leads to psychological contract breach. The psychological contract breach (PCB) will lead to behavior which violates organizational norms or threatens the wellbeing of the organization. Previous studies have suggested that psychological contract breach is associated with negative outcomes such as decrease in perceived obligations to one's employer, lowered citizenship behavior and reduced commitment and satisfaction (Robinson, Kraatz, and Rousseau 1994). Turnover intentions are strongly related with PCB (Agarwal 2014). PCB increases the tendency to leave the organization (Suazo et al., 2005). Therefore, the perception of psychological contract breach among teachers can be detrimental to the educational institutions. It is imperative for the institutions to know the perception of teachers about the breach or fulfillment of psychological contract from their employers and to take corrective measures if there is a perception of breach.

The recent studies on psychological contract have identified generally two dimensions of psychological contractrelational and transactional. Citing Rousseau \& Parks (1993), Guzzo, Noonan, and Elron (1994) state that 
relational contract consists of elements which are "pertaining to personal, socio-emotional, and value-based". As cited by Zhao et al., (2007) transactional contracts are those contracts which are "specific, monetizable exchanges over a limited period of time (obligations about pay)" (Robinson, Kratz, \& Rousseau, 1994).

Irrespective of the several studies made on the impact of psychological contract breach on organizational outcomes, the researchers have been unable to locate studies made on the impact of the different dimensions of psychological contract breach separately on employee reactions and behavior. Studies on the moderating effect of tenure and educational levels on these relationships are also recent, albeit studies have been made on the effect of these moderating factors on the relationship between psychological contract breach and various outcomes. Agarwal and Bhargava (2013) have studied the effect of PCB on work engagement and affective commitment and moderating effect of employee's tenure and educational level on these relationships. This study is an attempt to examine the impact of both dimensions (relational contract breach and transactional contract breach) of psychological contract breach separately on job satisfaction and turnover intention among self-financing college teachers. The study seeks to uncover the moderating effect of tenure on these relationships.

The rationale for selecting this topic for our study is the increasing attrition rate among college teachers especially in self-financing colleges. The well-paid and lucrative jobs in the corporate may be exerting a pull on the college teachers luring them to join the corporate. Likewise, better job security, higher salary, less stress and more freedom in government and government-aided colleges will be enticing them to move out of their current institutions. In addition to this, there may be other factors playing a crucial role in their exit. With this study we are making an effort to find out if the factors that cause this attrition, such as lack of job satisfaction, are derived from psychological contract breach. Research suggests that the basic groups to which people belong, such as age, gender, tenure and education levels have strong influence on their perceptions and attitudes (Pfeffer, 1983; Hall \&Buttram, 1994; Williams \& O’Reilly 1998; Kim, Murrmann \& Lee, 2009). Empirical studies suggest that tenure has significant influence on the relationship between psychological contract breach and engagement and commitment (Agarwal and Bhargava 2013). The current study makes an attempt to understand the influence of tenure on the relationship between two dimensions of psychological contract breach and job satisfaction and turnover intention.

\section{LITERATURE REVIEW}

\section{A. Psychological Contract Breach}

Chris Agyris (1960) devised the term "psychological work contract” which referred to the implicit understanding between a group of employees and their foreman. Edgar Schein (1965) extended the concept to define it as the unwritten expectations between every member of an organization and the managers in the organization. A healthy relationship between the employer and employee has become essential for the survival of the organization.

Therefore, any breach of this contract will lead to breaking the employer-employee relationship and in turn to the decline of the organization. Psychological contract is the employee's beliefs about explicit and implicit promises made to them by the employer in return to the time and effort of the employees towards the organizations (Rousseau, 1995).

According to Morrison \& Robinson (1997), "Breach refers to the cognition that one's organization has failed to meet one or more obligations within one's PC in a manner commensurate with one's contributions”. Psychological contract consists of employees' expectation about what they owe their employers (loyalty, commitment, hard work) in return of what their employers owe them ( reasonable compensation, healthcare benefits, opportunities for career growth) (Coyle-Shapiro \& Kessler, 2000). While healthy psychological contract leads to positive outcomes, psychological contract breach (PCB) leads to negative results. Several studies are made to suggest that $\mathrm{PCB}$ is positively related to turnover (Bunderson S.J. , 2001), positively related to cynicism (Pate et al., 2003; Bunderson, 2001), negatively related to organizational commitment (Pate et al., 2003; Zhao et al., 2007; Bunderson, 2001), negatively related to organizational citizenship behavior (Suazo\& StoneRomero, 2011) and negatively related to job satisfaction (Suazo, 2009).

\section{Relational Contract breach and Transactional Contract Breach}

Two major types of psychological contracts have been identified and evaluated- transactional and relational (Rousseau 1990, 1995; Herriot, Manning \& Kidd 1997; Anderson \& Schalk 1998). Relational contracts are based on obligations built on exchange of socio-emotional factors such as loyalty and support, while transactional contracts are centered on short-term monetary agreements (Grimmer and Oddy, 2007). Relational contracts are more concerned with "the relationship between an employee and an employing organization” (Guzzo et al.,., 1994). Long term interchanges will that will build relationship between an employee and employer contribute to relational contracts (Robinson, Kratz, \& Rousseau, 1994). With a transactional contract, employees are more concerned with compensation and personal benefits than with training, career development and provision of job security. Citing Robinson \& Rousseau (1995)'s statement that the employees attach relational contract breach to miscommunication from the employers' part, and not as a purposeful betrayal, Zhao et.al., (2007) argue that a breach of transactional contract will create a more negative impact on employee reactions than a relational contract breach will do. 


\section{B. Effects of Psychological Contract Breach on Job Satisfaction}

The consequences of psychological contract breach are the most widely discussed areas of psychological contract literature. An employee who feels that his / her expectations are not met by the employer, is less likely to feel satisfied with the job. Job satisfaction is the feeling of fulfillment or enjoyment one gets from the job. Locke (1976) considered job satisfaction as a pleasurable or positive emotional state resulting from the appraisal of one's job or job experience. According to Morse (1953), job satisfaction depends upon the content of the job, identification with the organization, financial status and group unity. Research studies provide substantial indication that breach of psychological contract is negatively related to job satisfaction (Abu Doleh et al., 2015, Xie et al., 2015, Suazo 2009, Zhao et al., 2007, Pate et al., 2003, Kikul \& Lester 2001)

\section{Effects of Psychological Contract Breach on Turnover Intention}

Turnover intention is a measurement of employee's plan to leave the organization. Turnover intentions are more strongly related to Psychological contract breach than actual turnover (Agarwal, 2014). Psychological contract breach intensifies the tendency of an employee to leave the organization (Raja et al., 2004; Suazo et al., 2005). Studies suggest that psychological contract breach is correlated to turnover intentions ((Shahnawaz\&Goswami, 2012; CoyleShapiro \& Kessler, 2000; Robinson, 1996; Robinson \& Morrison, 1995; Robinson \& Rousseau, 1994; Rousseau, 1995).

\section{OBJECTIVES OF THE STUDY}

1. To study the effect of relational contract breach and transactional contract breach on job satisfaction and turnover intention.

2. To understand the moderating effect of tenure on the relationships between relational contract breach and each of the reactions studied.

3. To understand the moderating effect of tenure on the relationships between transactional contract breach and each of the reactions studied.

\section{THEORETICAL FRAMEWORK}

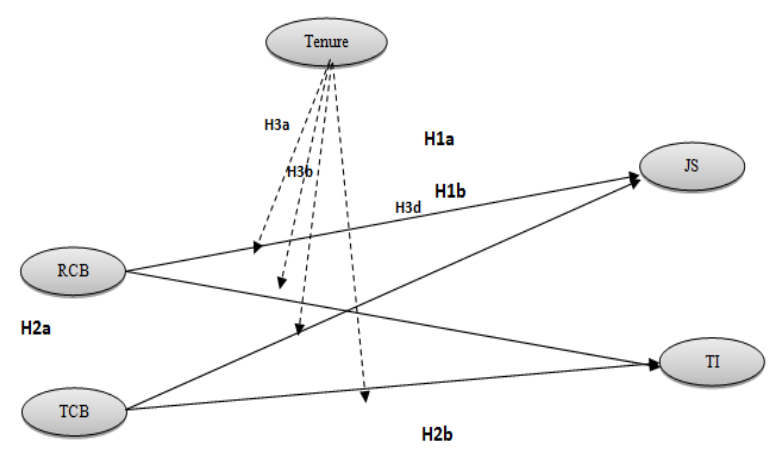

Fig. 1 Theoretical model developed for the study

\section{HYPOTHESES}

Hypothesis 1a: RCB is negatively related to Job satisfaction Hypothesis $1 b$ : RCB is positively related to turnover intention

Hypothesis 2a: TCB is negatively related to Job satisfaction Hypothesis 2b: TCB is positively related to turnover intention

Hypothesis 3a: Tenure moderates the relationship between RCB and JS

Hypothesis $3 b$ : Tenure moderates the relationship between RCB and TI

Hypothesis 3c: Tenure moderates the relationship between TCB and JS

Hypothesis 3d: Tenure moderates the relationship between TCB and TI

\section{RESEARCH METHOD}

Researchers collected data from 228 college teachers working in various self-financing colleges of Ernakulam District in Kerala. Out of this, 112 (49.1\%) were males and 116 (50.9\%) were females. The age of the respondents was distributed from 24 to 63 years and $46 \%$ of the respondents were below 30 years of age.

\section{A. Instrument}

A 28-item scale developed by Tran Huy Phuong (2013) as a composite measure of perception of psychological contract breach, has three dimensions- job characteristic, work environment, and compensation. This was used as the base for developing our questionnaire for measuring our predictor variables- RCB and TCB. The job characteristic and work environment dimension were considered as RCB components and compensation questions were considered for measuring TCB. Out of the total 16 questions that were used under job characteristic and work environment, 7 questions were considered for measuring RCB and additional 3 questions validated by us and suitable for the sample were used to compile a total of 10 questions for measuring RCB.

Out of the total 12 questions from compensation dimension, 5 were considered to make a questionnaire for measuring TCB. The scale for measuring job satisfaction (6-item) was developed by using 3 questions from a 36-item scale for job satisfaction by Yufan Liu (2005) and 3questions from a 20item scale for job satisfaction (Minnesota satisfaction questionnaire by Weiss, Dawis, England, \&Lofquiz, 1967). A 3-item scale developed by Mobley, Horner and Hollingsworth (1978) was used to measure turnover intention. The tenure of the respondents was based on their experience with the current institution; the sample consisted of respondents with minimum 3 month experience and a maximum of 14 years with their current institutions. The organizational tenure was measured by one open-ended question which asked for the number of years the respondents had worked with the organization. The tenure 
was grouped into five classes- 1 - 3 years, 4-5 years, 6-10 years, 11-15 years and more than 15 years. Warp PLS 6.0, PLS based software, was used structural equation modeling and hypothesis testing. One question each from RCB was dropped because of validity problems.

\section{DATA ANALYSIS AND RESULT}

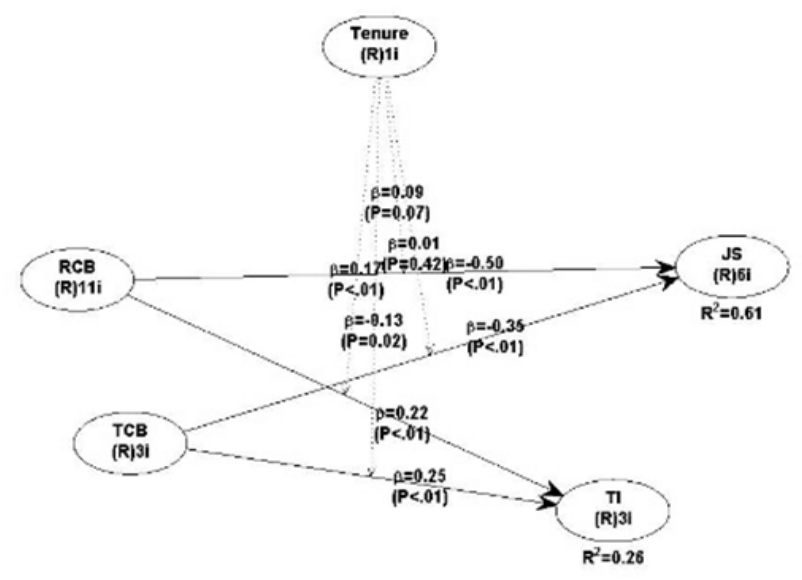

Fig. 2 SEM using Warppls6.0

An exploratory factor analysis was done using SPSS 20, to identify six factors before subjecting the data for further analysis with Warppls6.0. The structural equation modelling (SEM) developed using Warppls is given (Figure 2). Results of model fit are given in Table 1 . The reliability and validity tests done were found to be satisfying (Chronbach's alpha above 0.7 , loading more than 0.5 and cross loading less than 0.5 ) as shown in Table I.

\section{A. Testing Hypotheses}

Hypotheses 1a predicted a negative relationship between RCB and Job satisfaction. The beta value $(-0.499)$ and p value $(<0.001)$ show that there is a significant negative relationship. Hypotheses $1 \mathrm{~b}$ predicted a positive relationship between RCB and Turnover Intention. The results as shown in Table 2 indicate a significant positive relationship (beta value $=0.219, \mathrm{p}=<0.001$ ). A negative relationship was predicted between TCB and Job satisfaction by hypotheses 2a; and a positive relationship between TCB and turnover intention was predicted by hypotheses $2 \mathrm{~b}$. The results (Table II) support both hypotheses.

Hypotheses $3 \mathrm{a}$ and $3 \mathrm{~b}$ predicted moderating effect of Tenure on the relationships between RCB and job satisfaction and turnover intention. The result indicated that Tenure had a moderating effect only on the RCB- turnover relationship; the beta value decreased from 0.219 to 0.172 implying that tenure has slightly reduced the strength of the relationship. The moderating effects of Tenure on the relationships between TCB and Job satisfaction and turnover intention were predicted by hypotheses 3c and 3d.

TABLE I QUALITY CRITERIA AND OBSERVED VALUES

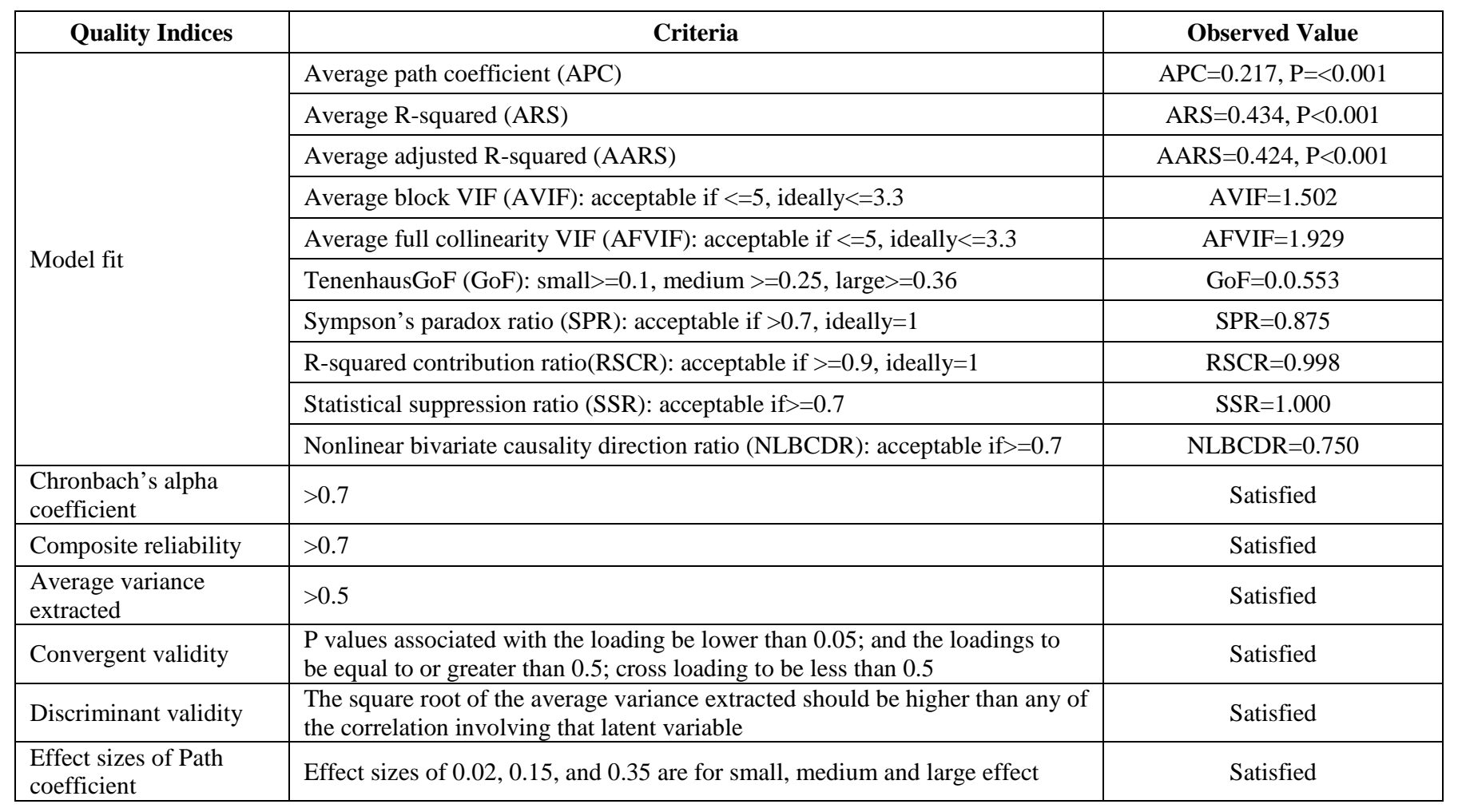


TABle Ii Result Of Hypothesis Testing (Source: Primary Data)

\begin{tabular}{|c|l|c|c|c|}
\hline Hypothesis & \multicolumn{1}{|c|}{ Statement } & Beta value & P value & Interpretation \\
\hline 1a & RCB is negatively related to Job Satisfaction & -0.499 & $<0.001$ & Supported hypothesis \\
\hline 1b & RCB is positively related to turnover intention & 0.219 & $<0.001$ & Supported hypothesis \\
\hline 2a & TCB is negatively related to Job satisfaction & -0.350 & $<0.001$ & Supported hypothesis \\
\hline 2b & TCB is positively related to turnover intention & 0.252 & $<0.001$ & Supported hypothesis \\
\hline 3a & Tenure moderates the relationship between RCB and JS & 0.095 & 0.073 & Not supported the hypothesis \\
\hline 3b & Tenure moderates the relationship between RCB and TI & 0.172 & 0.004 & Supported the hypothesis \\
\hline 3c & Tenure moderates the relationship between TCB and JS & 0.014 & 0.418 & Not supported hypothesis \\
\hline 3d & Tenure moderates the relationship between TCB and TI & -0.132 & 0.021 & Supported the hypothesis \\
\hline
\end{tabular}

It was found that while tenure did not have any significant effect on the TCB-job satisfaction relationship ( $\mathrm{p}=0.418$ ), it had slight effect on the TCB-turnover intention relationship.

\section{DISCUSSION AND CONCLUSION}

The findings of this study has revealed that there were significant relationships between relational contract breach and job satisfaction and turnover intentions as well as between transactional contract breach and job satisfaction and turnover intentions. As the breach of relational contract and transactional contracts occurred, the job satisfaction of the teachers towards their institutions was reduced.

A breach of relational and transactional contracts led to increased turnover intentions among the teachers. It was interesting to note that a relational contract breach had more negative effect on the job satisfaction among teachers, compared to a transactional contract breach; however, a transactional contract breach influenced the teachers more in their intention to leave the organization compared to a relational contract breach. Considering the moderating effect of tenure, it moderated the relationship between relational contracts breach and turnover intention but not between RCB and job satisfaction. It suggested that the effect of relational contract breach on teachers' job satisfaction was unaffected irrespective of the change in tenure.

As the tenure of college teachers increased the effect of relational contract breach on turn over intention decreased. Conversely, tenure moderated the TCB-TI relationship but not TCB-JS relationship. This showed that the effect of compensation and salary on job satisfaction did not vary much irrespective of the tenure.

This study has several managerial implications. The understanding that any type of breach of contract (relational or transactional) can lead to negative reactions from the college teachers should prompt the managements of the self-financing colleges to look into their style relationship with the teachers. A healthy and positive relationship with the teachers where they have more autonomy, their work being appreciated, they enjoy working, they get paid commensurate their work, will enhance the teachers' job satisfaction and will reduce their intention to leave. The lack of proper compensation or monetary benefits will lead to turnover intention more than any other factor and this intention will not be reduced by the employees' years of experience with the organization.

This study has some limitations. The study has taken into consideration only two organization outcomes, where studies have shown that there are other possible outcomes such organizational commitment, organizational citizenship behavior, and cynicism. For further research study, these dependent variables can be considered and the role of the moderating variables on the relationships between RCB and the new dependent variables and TCB and the new dependent variables can be tested.

\section{REFERENCES}

[1] Abu-Doleh J, D., \& Hammou, D. M. (2015). The IMpact of Psychological ONctact Breach on Organizational Outcomes: The moderating role of personal beliefs. JCS, 1, 2, 34-54.

[2] Agarwal, U. A. (2014). Examining PCB-Outcomes Relationship: Moderating Role of Individualism. Vikalpa, 39(2), 99-112.

[3] Agarwal, U., \& Bhargava, S. (2013). Effects of psychological contract breach on organizational outcomes: Moderating role of tenure and educational levels. Vikalpa, 38(1), 13-26.

[4] Anderson, N. \&. (1998). The psychological contract in retrospect and prospect. Journal Organizational Behaviour, 19, 637-47.

[5] Argyris, C. (1960). Understanding Organizational Behavior 12. Homewood, Illinois: Dorsey Press.

[6] Bunderson, J. S. (2001). How work ideologies shape the psychological contracts of professional employees: doctor's responses to perceived breach. Journal of Organizational Behavior, 22, 717-741.

[7] Conway, N., \& Briner, R. B. (2002). A daily diary study of affective responses to psychological contract breach and exceeded promiese. Journal of Organizational Behavior, 23, 287-302.

[8] Coyle-Shapiro, J., \& Kessler, I. (2000). Consequences of the psychological contract for the employment relationship: a large scale survey. Journal of Management Studies, 37(7), 903-930.

[9] Grimmer , M., \& Oddy, M. (2007). Violation of the Psychological Contract: The Mediating effect of Relational versus Transactional Beliefs. Australian Journal of Management, 32.

[10] Guzzo, R., Noonan, K., \& Elron, E. (1994). Expatriate managers and the psychological contract. Journal of Applied Psychology, 79, 617626.

[11] Hall, R. H. (1994). Sociology of work: Perspectives, analyses, and issues. CA: Pine Forge Press, Thousand Oaks.

[12] Herriot, P., Manning, W., \& Kidd, J. M. (1997). The content of the Psychological Contract. British Journal of Management, 2, 151-162. 
[13] Kickul, J. K. (2002). Promise breaking during radical organizational change: do justice interventions make a difference? Journal of Organizational Behavior, 23, 469-488.

[14] Kickul, J., \& Lester, S. W. (2001). Broken promises: Equity sensitivity as a moderator between psychological contract breach and employee attitudes and behavior. Journal of Business and Psychology, 16(2), 191-217.

[15] Kim, B. C. (2009). Moderating effects of gender and organizational level between role stress and job satisfaction among hotel employees. International Journal of Hospitality Management, 28(4), 612-619.

[16] Lester, S. T. (2002). Not seeing eye to eye: Differences in supervisor and subordinate perceptions of and attributions for psychological contract breach. Journal of Organizational Behavior, 23, 39-56.

[17] Liu, Y. (2005). Investigating turnover intention among emergency communication specialists. Scholar Commons, 65-66.

[18] Locke, E. (1976). The nature and causes of job satisfaction. Handbook of Industrial and Organizational Psvchology. Chicago, Handbook of Industrial and Organizational Psvchology, 45, 12971349.

[19] Mobley, W. H. (1978). An evaluation of precursors of hospital employee turnover, Journal of Applied Psychology, 63(4), 408-414.

[20] Morrison, E. W., \& Robinson, S. L. (1997). When employees feel betrayed: a model of how psychological contract violation develops. Academy of Management, 22(1), 226-256.

[21] Morse, N. C. (1953). Satisfaction in the white-collar job. Survey Research Center.

[22] Mowday, R. T., Steers, R. M., \& Porter, L. W. (1979). The measurement of Organizational Commitment. Journal of Vocational Behavior, 14, 224-247.

[23] Pate, J., Martin, G., \& McGoldrick, J. (2003). The impact of psychological contract violation on employee attitudes and behaviour. Employee Relations, 25(6), 557-573.

[24] Pfeffer, J. (1983). Organizational demography. Research in Organizational Behavior, 5(1), 299-357.

[25] Phuong, T. H. (2013). How to measure Psychological Contract Breach as a predictor of workplace outcomes: evidence from Vietnam. The Macrotheme Review, 2(2), 32-42.

[26] Raja, U., Johns, G., \& Ntalianis, F. (2004). The Impact of Personality on Psychological Contracts. Academy of Management Journal, 47(3), 35-367.

[27] Robinson, S. A. (1994). Violating the psychological contract: Not the exception but the norm. Journal of Organizational Behavior, 15, 245259.

[28] Robinson, S. L. (1995). Psychological contracts and OCB: The effect of unfulfilled obligations on civic virtue behavior. Journal of Organizational Behavior, 16, 289-298.
[29] Robinson, S. L. (1996). Trust and Breach of the Psychological Contract Breach. Administrative Service Quarterly, 41, 574-599.

[30] Robinson, S., Kraatz, M. S., \& Rousseau, D. M. (1994). Changing Obligations and the Psychological contract: A longitudinal study. Academy of Management Journal, 37(1), 137-152.

[31] Rousseau, D. (1990). 'New hire perceptions of their own and their employer's obligations: A study of psychological contracts'. Journal of Organizational Behaviour, 11(5), 389-400.

[32] Rousseau, D. (1995). Psychological contracts in organizations: Understanding written and unwritten agreements. Thousand Oaks: Sage Publications.

[33] Rousseau, D. M. (1993). The contracts of individuals and organizations. In L. L. Staw. Greenwich, CT: JAI Press.

[34] Schein, E. H. (1965). Organizational Psychology. Englewood Cliffs, NJ: Prentice Hall.

[35] Shahnawaz, M. A. (2012). Effect of Psychological Contract Violation on Organizational Commitment, Trust and Turnover Intention in Private and Public Sector Indian Organizations. Vision: The Journal of Business Perspective, 15, 209-217.

[36] Suazo, M. M. (2005). The Role of Perceived Violation in Determining Employees' Reactions to Psychological Contract Breach. Journal of Leadership and Organizational Studies, 12, 24-36.

[37] Suazo, M. M. (2009). The mediating role of psychological contract violation on relations between psychological contract breach and work-related attitudes and behaviors. Journal of Managerial Psychology , 24(2), 136-160.

[38] Suazo, M. M., \& Stone-Romero, E. F. (2011). Implications of Psychological Contract Breach: A percieved organizational support perspective. Journal of Management Psychology, 26(5), 366-382.

[39] Sutton, G. A. (2004). Integrating expectations, experiences, and psychological contract violations: A longitudinal study of new professionals. Journal of Occupational and Organizational Psychology, 77, 493-514.

[40] Weiss, D., Dawis, R., England, G., \& Lofquist, L. (1967). University of Minnesota, Minneapolis. Manual for the Minnesota Satisfaction Questionnaire, 111.

[41] William, K. Y., \& O'Reilly, C. A. (1998). Demography and Diversity: A review of 40 years of research. Res Organ Behav, 20, 77-140.

[42] Xie, X., Liu, H., \& Deng, H. (2015). Psychological Contract Beah and Turnover Intention: The inermediary role of job satisfaction. Opne Journal of Business Management, 3(3), 371-379.

[43] Zhao, H., Wayne, S. J., Glibkowski, B. C., \& Bravo, J. (2007). The impact of psychological contract breach on work-related outcomes: a meta-analysis. Personnel Psychology, 60, 647-680. 